\title{
Relationship between the Levels of the Physical Literacy of Children Military Families with Job Characteristics of their Fathers
}

\author{
*Valadi. S1 \\ VaezMousavi. M² \\ Naji. $\mathrm{M}^{3}$ \\ 1- ( ${ }^{*}$ Corresponding Author) \\ MSc in Motor Behavior \\ Motor development, Young \\ Researches and Elites club, \\ Science and Research Branch, \\ Islamic Azad University, Tehran, \\ Iran. \\ Email: saeedv1992@gmail.com \\ 2- Ph.D. in Sport Psychologist, \\ Professor, Physical Education \\ and Sports Science Department, \\ Imam Hossain University, \\ Tehran, Iran. \\ 3- Ph.D. in Sport Management, \\ Assistant Professor, Physical \\ Education and Sports Science \\ Department, Imam Hossain \\ University, Tehran, Iran.
}

\begin{abstract}
Introduction: To achieve a desirable level of motor development and physicalmental competencies and develop a healthy and active lifestyle in all people in society, particularly children and families of the military and considering the nature of job their fathers' job, accurate principles on motor and exercise skills, called physical literacy principles, is required.
\end{abstract}

Objective: Present study aimed to determine the relationships between the levels of the physical literacy of children in the 8-12 age range with some natures of their military fathers' job.

Materials and Methods: The method is a descriptive-correlation in which a total of 171 children in the 8-12 age range were selected by multi-stage cluster sampling in districts 1, 4, 8 and 13 of Tehran and the Iranian version of the physical literacy test consisting of 4 subscales such as physical competence, daily physical activity, motivation and self-confidence, and knowledge and understanding was administered Further, Fathers completed a questionnaire about their occupational nature, corps, and their level of education. Findings were analyzed using descriptive statistics, ETA correlation coefficient, $\mathrm{t}$ - independent test, and one-way covariance analysis. Data were analyzed using SPSS 23.

Results: The physical literacy of children with staff fathers was more than those with father in the troop (Effect size $=0.36, \mathrm{t}=-4.558, \mathrm{P}<0.01$ ). Furthermore, the physical literacy of children with fathers working in educational-section was greater than those whose fathers work in operational section $(\mathrm{P}=0.05)$.

Discussion and Conclusion: Children's physical literacy is related to the occupational nature of military fathers. These job natures can affect the children's active lifestyles. Knowing this relationship affects the physical literacy of children in military families and the implementation of appropriate movement and sports programs is needed to increase the physical literacy of these children, especially among girls. Further studies on the impact of other factors on physical literacy should be conducted.

Keywords: Health Literacy, Health Behavior, Life Quality, Military Personnel, Physical Activity. 


\section{رابطه سطح سواد بدنى فرزندان خانوادههاى نظامى با ويزّى هاى شغلى يدران}

"سعيد ولدى'، سيد محمد كاظم واعظ موسوى ‘، مرتضى ناجى"

جكيده

مقدمه: به منظور دستيابى به سطح مطلوب رشد حر كتى و شايستخىهاى جسمانى -روانى و ايجاد يك سبك زندگى سالم و فعال در ميان همه افراد جامعه به ويزه خانوادهها و فرزندان قشر نظامى و با توجه به ويزگى هاى شغلى يدران، نيازمند اصول دقيقى از مهارتهاى حركتى و ورزشى هستيم كه اين اصول سواد بدنى نام دارند.

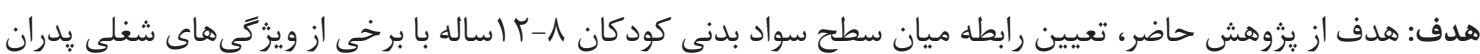
نظامى آنها بود. مواد و روشها: روش تحقيق توصيفى - ميدانى و از نوع همبستگى است؛ كه در آن با استفاده از روش نمونهَيرى خوشهاى

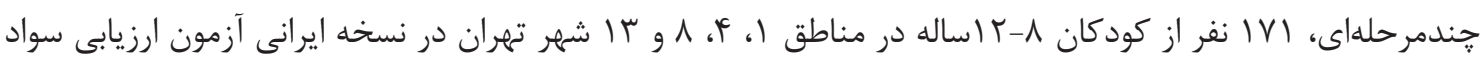

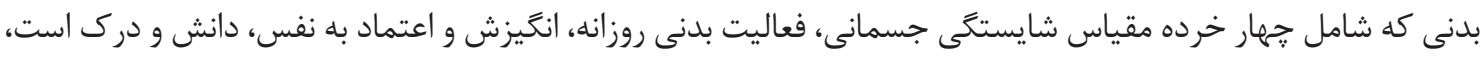

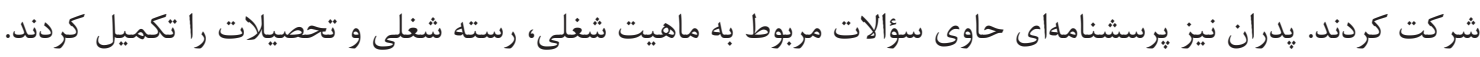

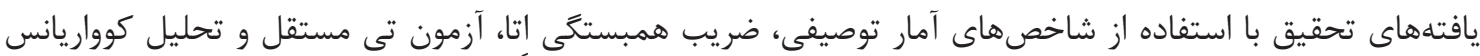
يكراهه تحليل شد. از نرمافزار SPSS نسخه سז جهت تحليل دادها استفاده شد.

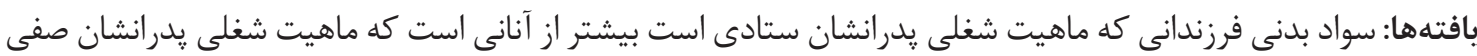

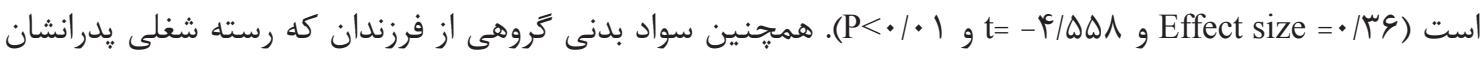

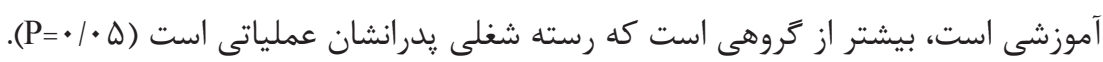

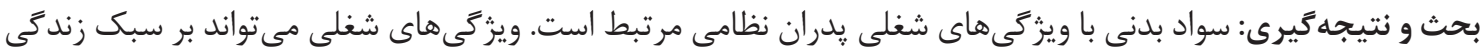

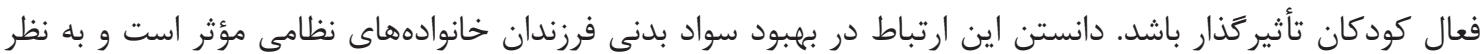
مى سد لزوم اجراى برنامههاى حركتى و ورزشى مناسب جهت افزايش سواد بدنى اين كودكان بهويزه براى دختران ضرورى

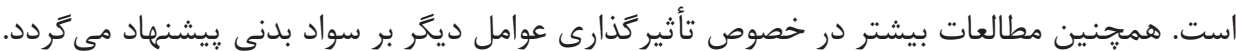
كلمات كليدى: برسنل نظامى، سواد سلامتى، رفتار سالم، فعاليت بدنى، كيفيت زندكى.

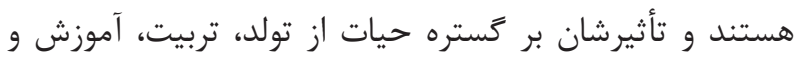
سلامت جسم و روان فرزندان تا تداوم و حفظ بقاى نوع بشر كاملاً

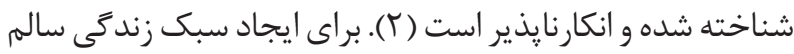

دوران كودكى، بلوغ و اوايل نوجوانى زمان مناسبى جهت شكل كيرى اندامى متناسب است كه از طريق بازىها و ارتباطات

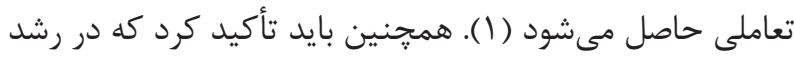


ترمبلاى و لويد (Tremblay \& Llyod) معتقدند كه ارزيابى جامع

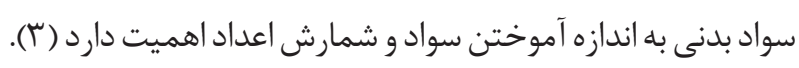

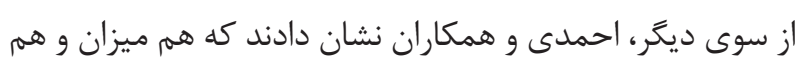
كيفيت حضور يدر در خانواده، ارتباط معنادارى با علائم اختلالات

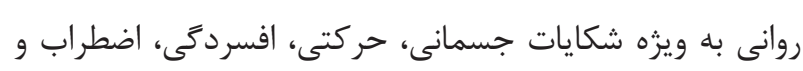

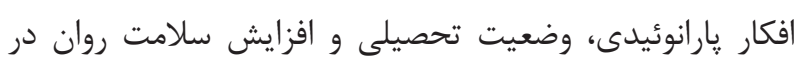

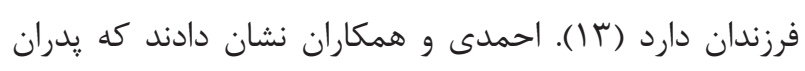

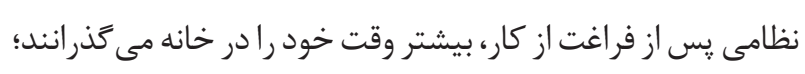
همين امر باعث شده است تا زنان و فرزندان خانواده بيشتر اوقات

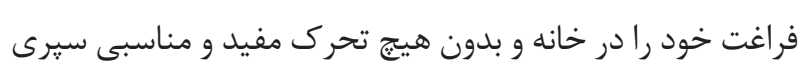

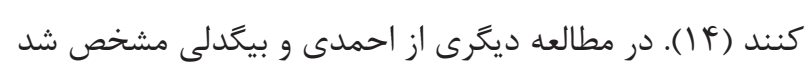

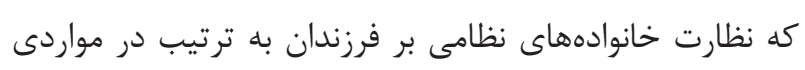

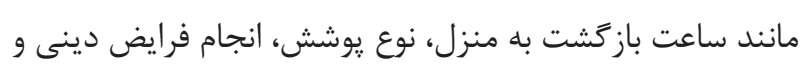

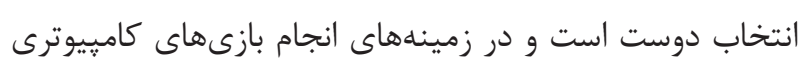

و مطالعه كتب كمترين نظارت وجود داد (هاب د). به نظر مىرسد يدران نظامى بر اساس مقتضيات شغلى، فشارهاى روانى بيشترى را تجربه مى كنند. از جمله اين فشارها مىتوان

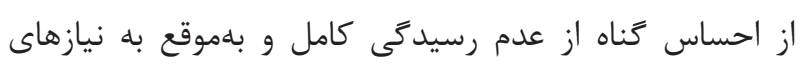
اعضاى خانواده، غيبتهاى طولانى و دورى از همسر و فرزندان،

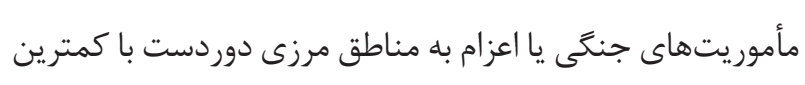

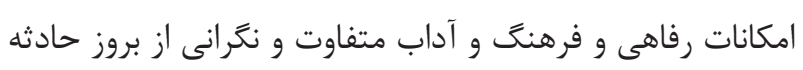

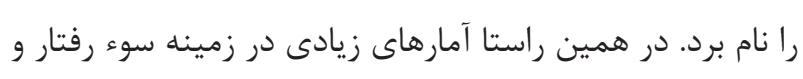
غفلت نسبت به سلامت روانى و جسمى فرزندان توسط نظاميانى

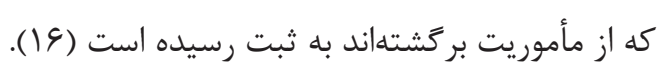

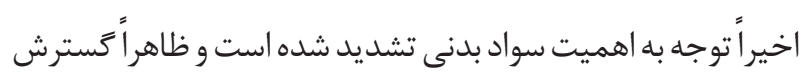

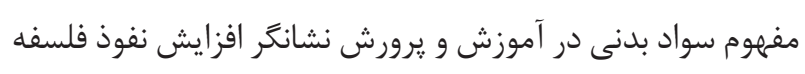

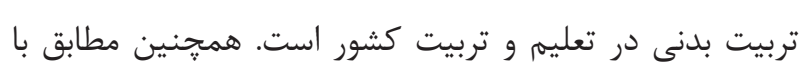

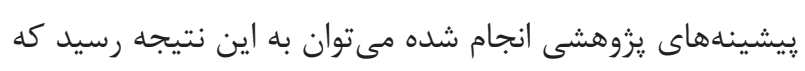

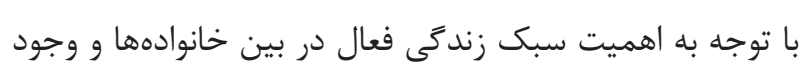

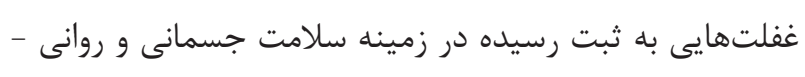

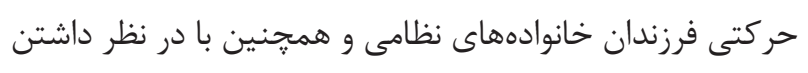

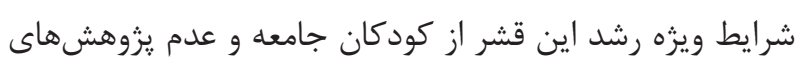

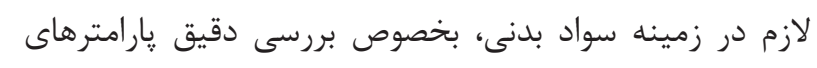

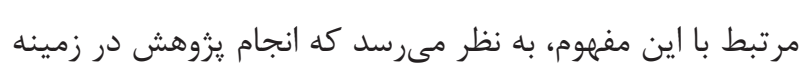

و فعال در كودكان، ضرورى است تا اصول دقيقى از مهارتهاى

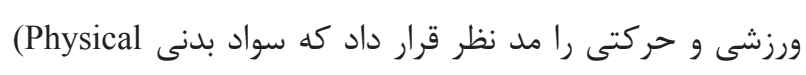
literacy) و ورزشى است كه به كودى اجازه مىدهد تا با انغيزه، اعتماد

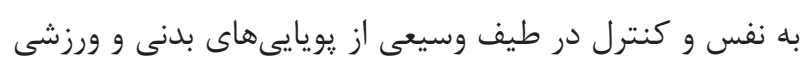

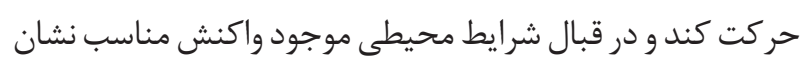

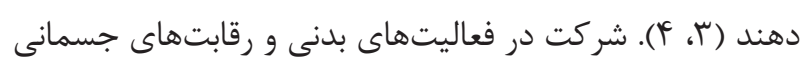
به رشد مهارتهاى حر كتى بنيادين، كسب آمادگى بدنى و بهببود تركيب بدن مىانجامد (ه، 9). طبق تعريف شوراى بينالمللى علوم ورزش و تربيتبدنى يونسكو (International Council of Sport Science and Physical Education of UNESCO)

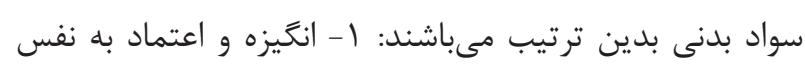
كه مربوط به بعد عاطفى و درك كودكان از توانايى خود در انجام

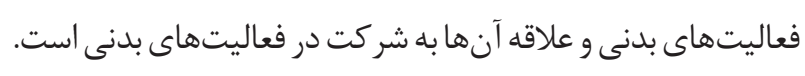

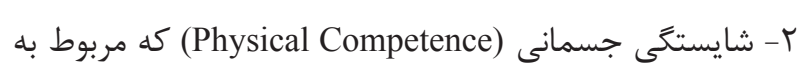

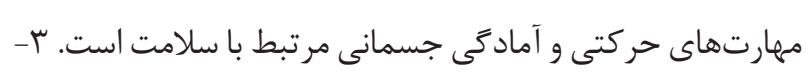
دانش و درى كه مربوط به بعد شناختى و درك كود كان از فعاليت

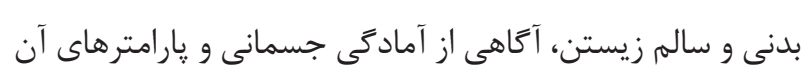

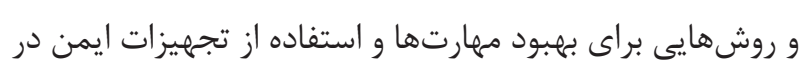

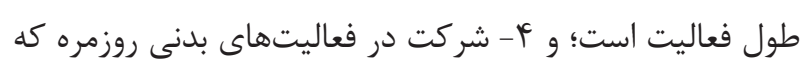

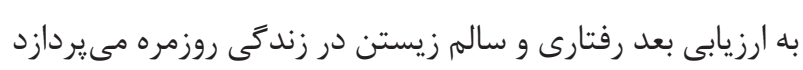

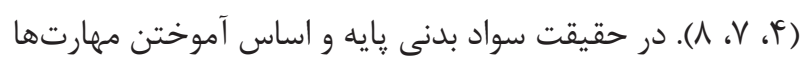

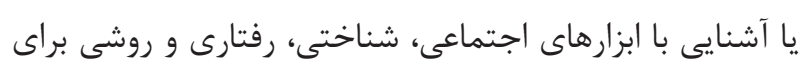

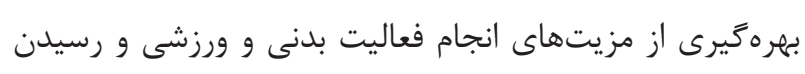
به لذتهاى بلندمدت و كسب موفقيت در طول عمر است (بآ).

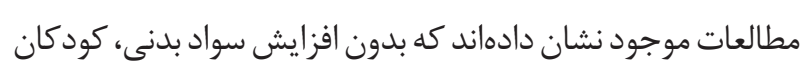

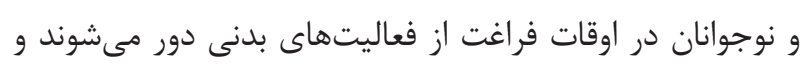
كارهاى غيرفعال را انتخاب مى كنند (1- • (1).

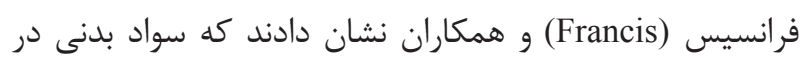

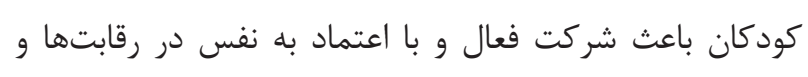

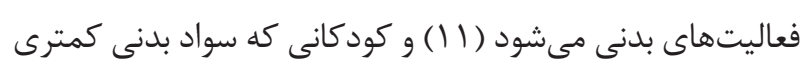
دارند در فعاليتهاى بدنى مشاركت كمترى مى كنند؛ و اين امر إنى خطر افزايش مشكلات براى سلامتى را افزايش مى دههد (I) (I). 
ارائه به يدر خانواده داده شد. لازم به ذكر است كه در زمان آغاز

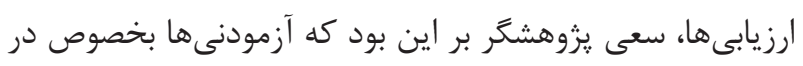

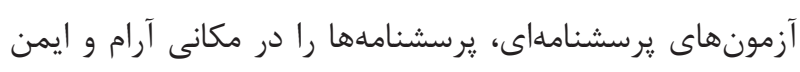

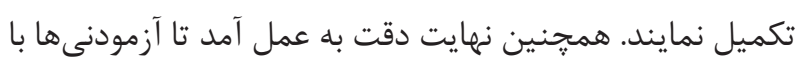

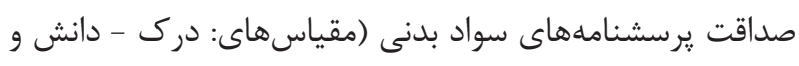

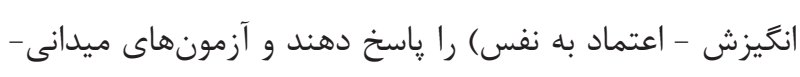

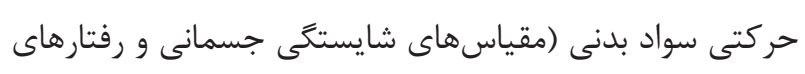

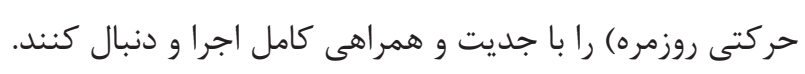
براى كردآورى دادهها از ابزار جامع ارزيابى سواد بدنى كانى هانادايى (Canadian Assessment Physical Literacy)

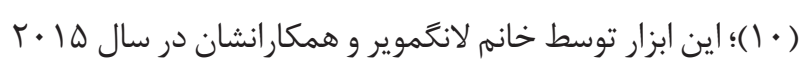

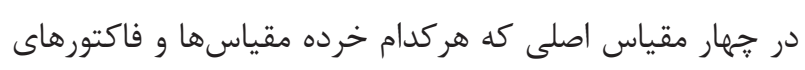
خاصى را مىسنجند، طراحى شده است.

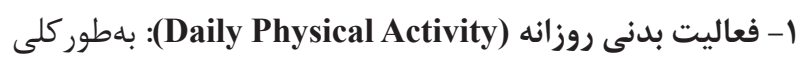
شامل اندازهزيرى و سنجش سطح فعاليت بدنى كودكان و سطح

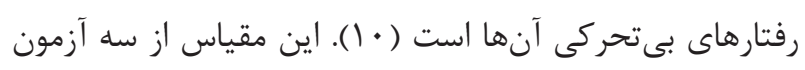
تشكيل شده است. الف) سنجش مستقيم فعاليت بدنى و با استفاده انهاه

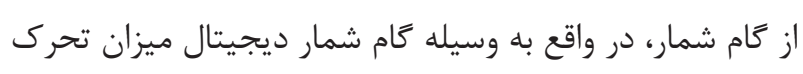

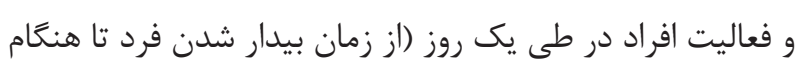

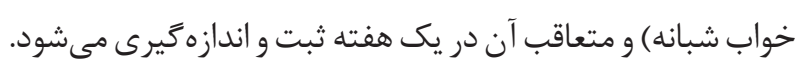

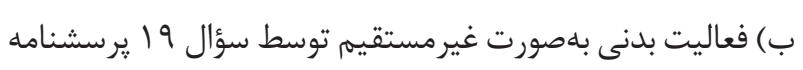

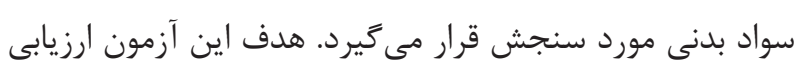

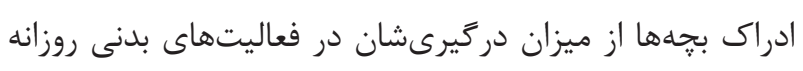

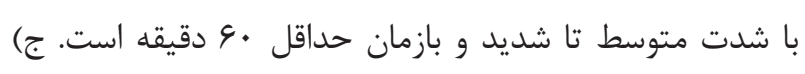

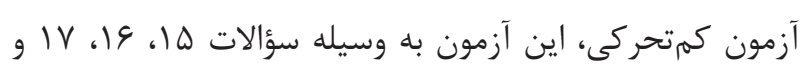

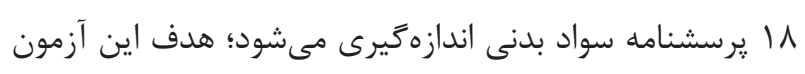
ارزيابى ثبت تعداد ساعاتى است كه كودى در روزهاى تعطيل و عادى هفته صرف تماشاى تلويزيون مى كند.

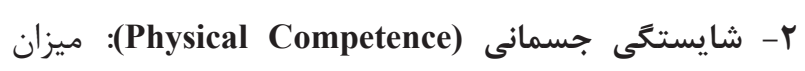
توانايى حركتى افراد را جهت مشاركت در فعاليتهاى جسمانى

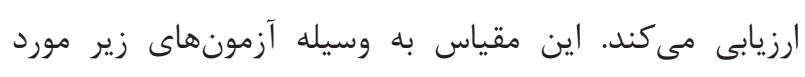

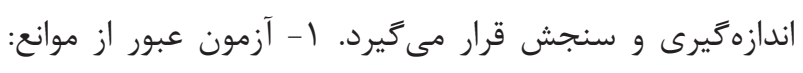

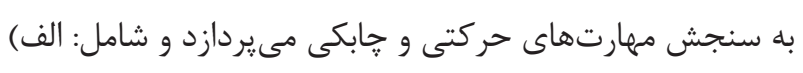

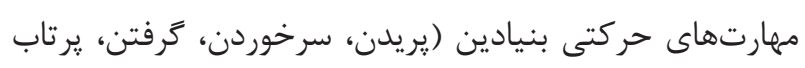

سواد بدنى اين افراد در اولويت يزوهشهاى تربيت بدنى باشد. بر اين اساس، در يزوهش حاضر رابطه بين سواد بدنى فرزندان نظامى با ماهيت و رسته شغلى بدرانشان مورد مطالعه قرار گرفت.

\section{مواد و روشها}

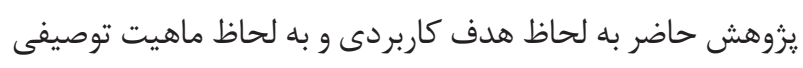

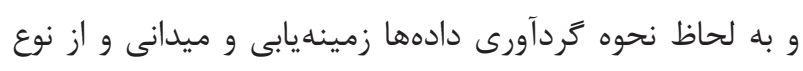

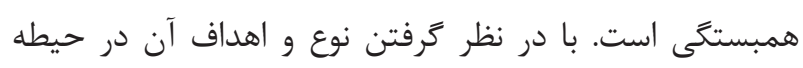

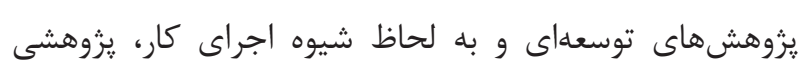

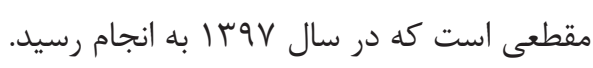

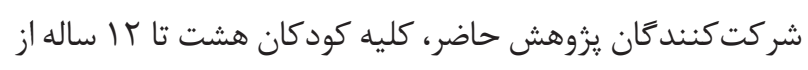

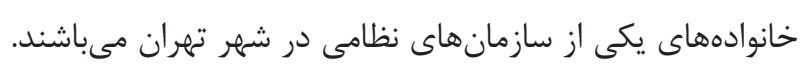

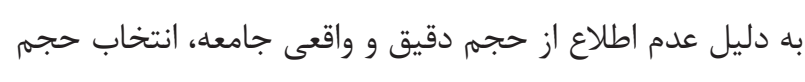

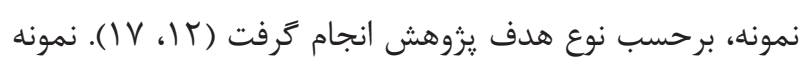

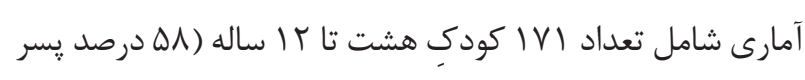

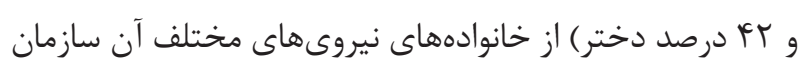

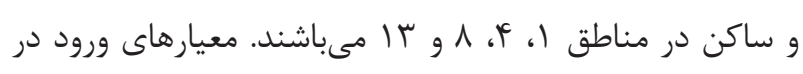

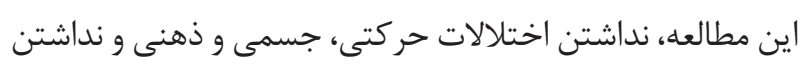
بيمارىهاى خاص نظير بيمارىهاى قبلى و عروقى، آنمى، فشار خون ديابت و همجنين داشتن سن 1 تا بال ال سال بود.

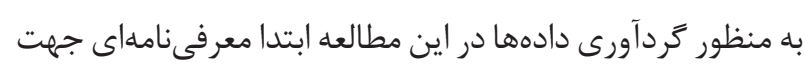
انجام اين يزوهش دريافت شد؛ پِ إن از ارائه معرفىنامه به سازمان

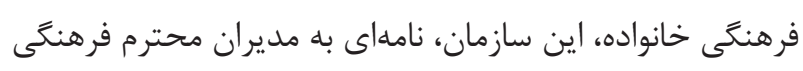

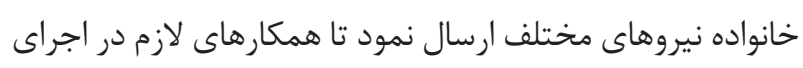

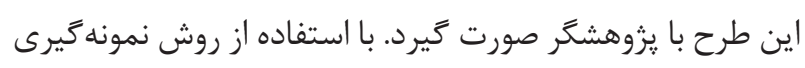

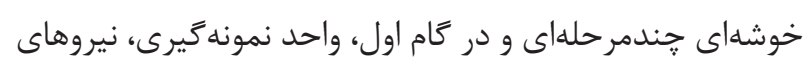

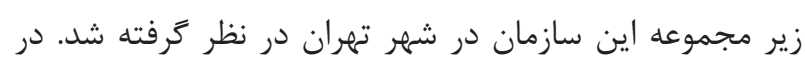

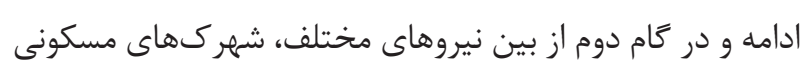

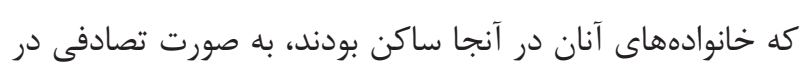

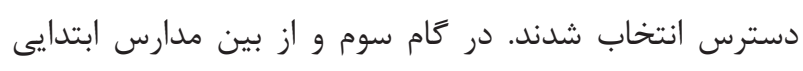

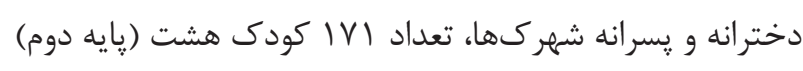

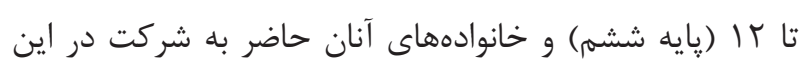

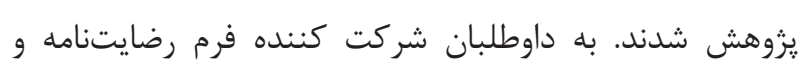

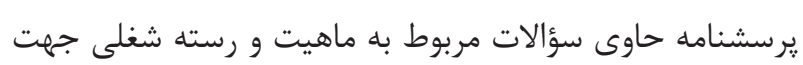


" Activity (CSAPPA)

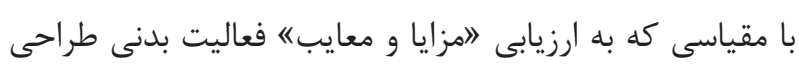

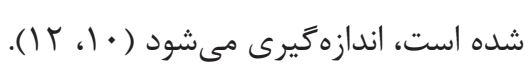

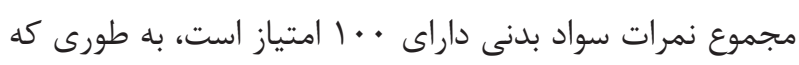

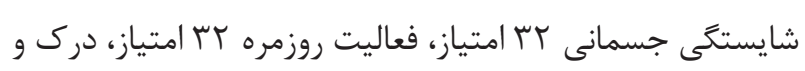

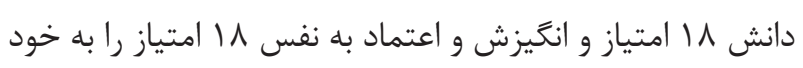

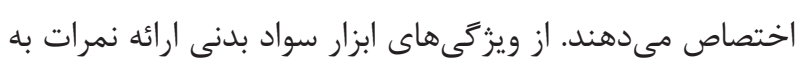

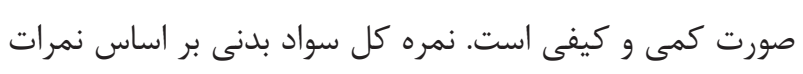

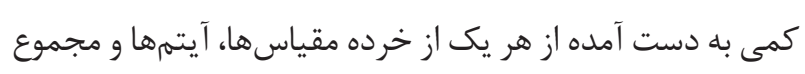
آنها محاسبه مىشود و طبقهبندى نمرات در جهار سطح كيفى و

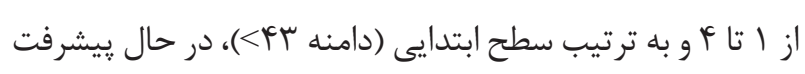

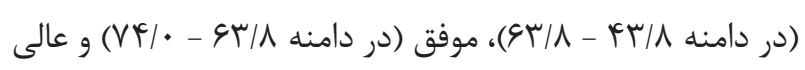

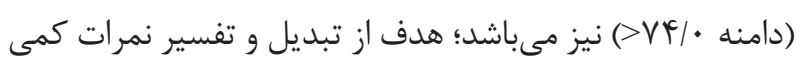

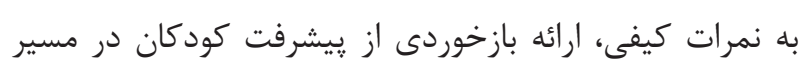

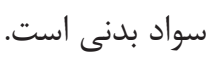

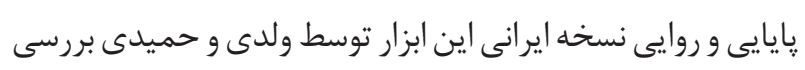

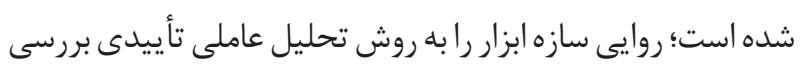

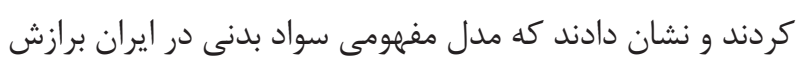

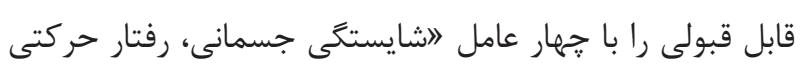

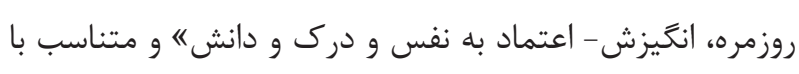

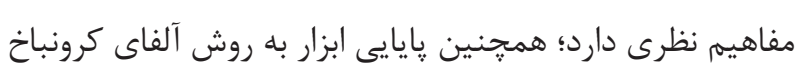

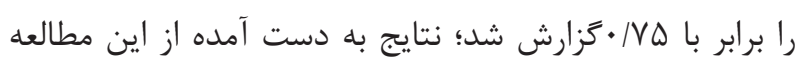

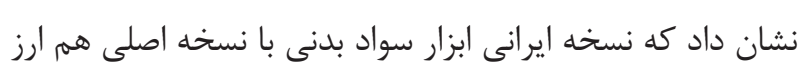

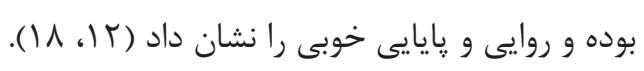

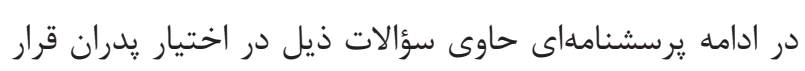

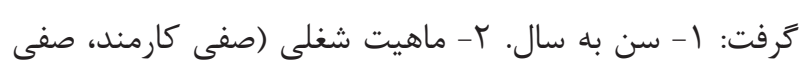

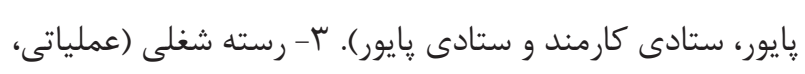

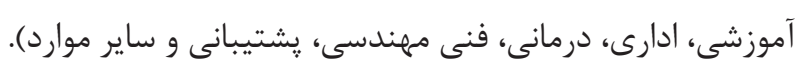

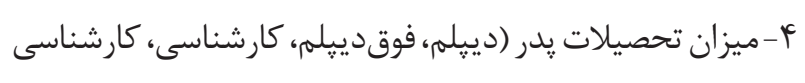
ارشد و دكترى) و ميزان تحصيلات مادر (دييلم، فوقدييلم، كارشناسى، كارشناسى ارشد و دكترى).

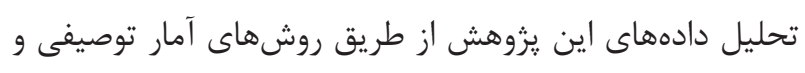

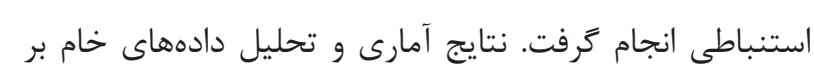
اساس اهداف و فرضيههاى يزوهش در قالب جدول و نمودار نشان
كردن، لى لى كردن و يرتاب كردن). ب) مهارتهاى تركيبى

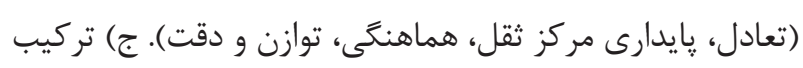

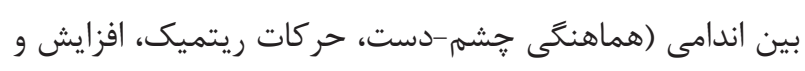

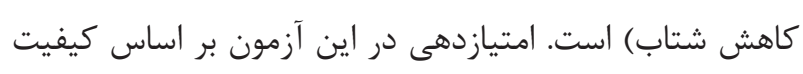

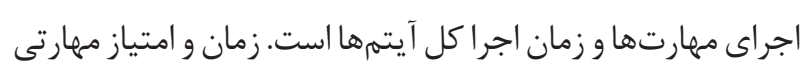

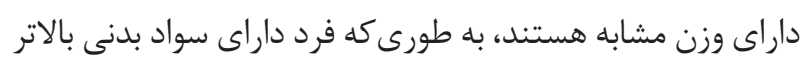
قادر به يافتن نسبت بهينه بين سرعت و دقت در اجراى آزمونها

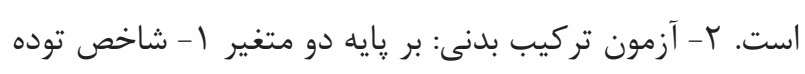

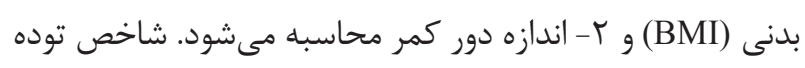
بدنى= وزن (برحسب كيلوكرم) / مجذور قد (برحسب متر مربع)

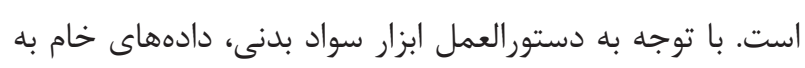

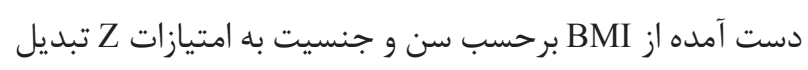
شدند. براى محاسبه امتيازات B BMI برحسب سن و و و جنسيت

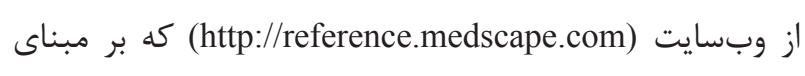
اطلاعات سازمان بهداشت جهانى (WHO) است، استفاده شد.

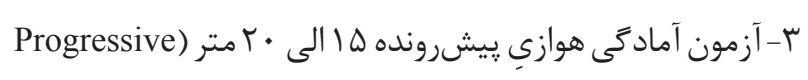
:(Aerobic Cardiovascular Endurance Run (PACER) test

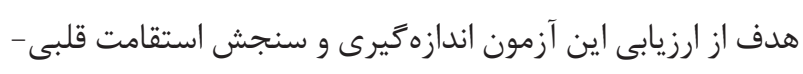

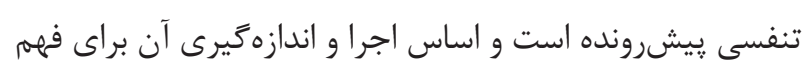

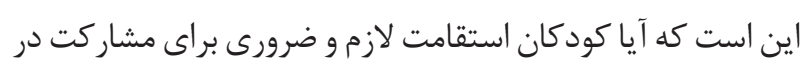

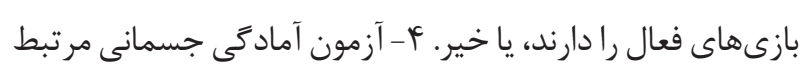

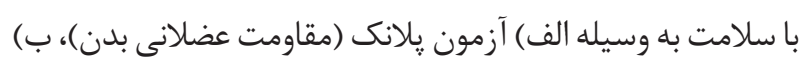

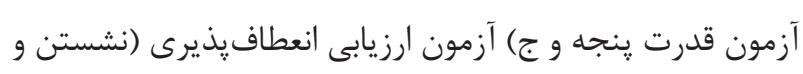

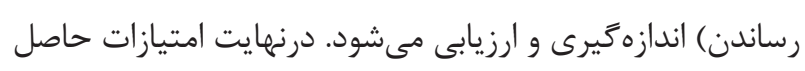

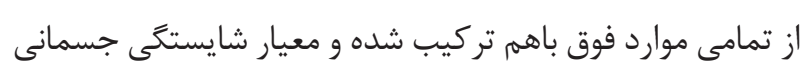
حاصل مىشود. r- درك و دانش (Knowledge \& Understanding): ميزان درك و آكاهى از فوايد ورزش و آمادگى جسمانى، ادراك سلامتى دانى

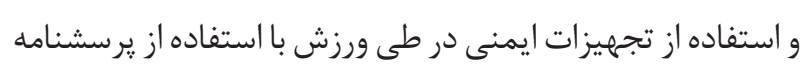
سواد بدنى ارزيابى مىشود. F أنغيزش و اعتماد به نفس (Motivation \& Confidence):

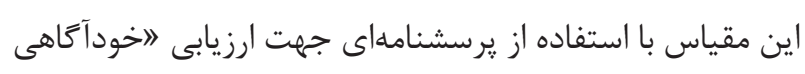
كود كان از كافى بودن و تمايل به فعاليت بدنى (Children’s Self Perception of Adequacy in and Predilection for Physical 
همجنين نتايج حاصل از بررسى نشان داد كه بين ميانكين نمره

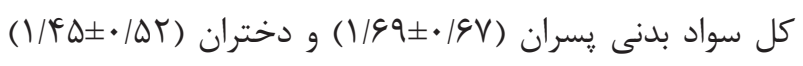

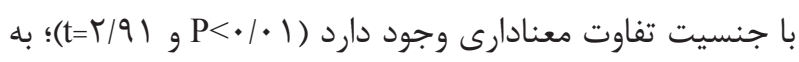

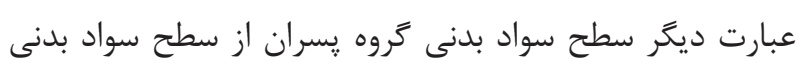
كروه دختران بالاتر بود.

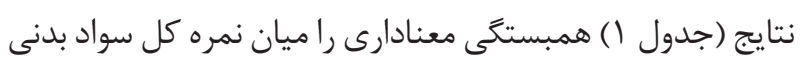

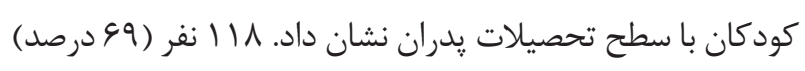

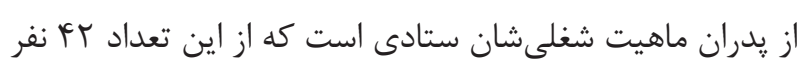

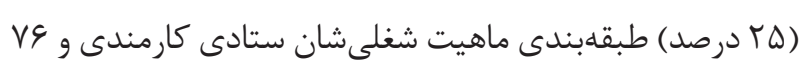

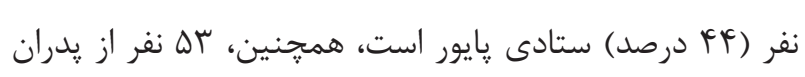
كروه نمونه ماهيت شغلىشان صفى است، به طورى كه 19 (11)

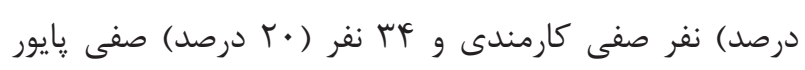

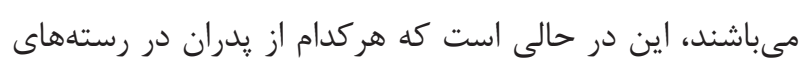

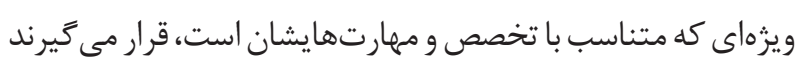

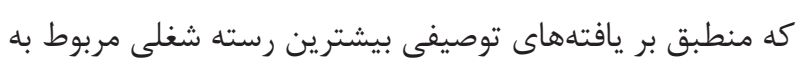

رسته عملياتى و كمترين آن مربوط به رسته درمانى است.

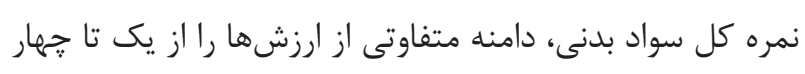

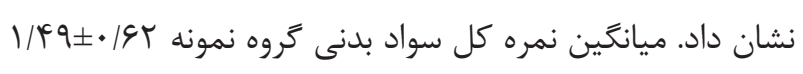
به دست آمد كه بر اساس طبقهبندى نمرات كيفى در سطح ابتدايى (ضعيف) ارزش كذارى مىشود؛ اما در بررسى تكتى لمى خرده

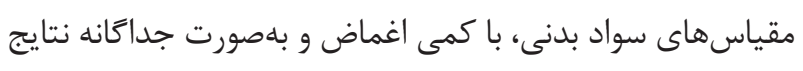

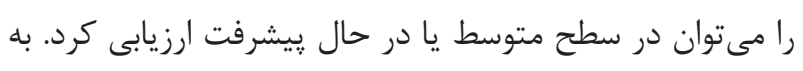

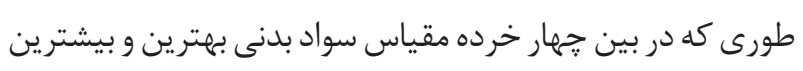

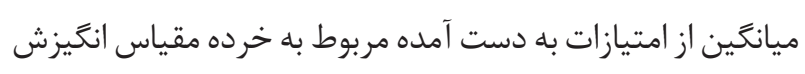

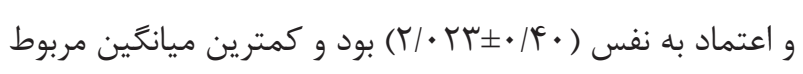

جدول ا- نتايج مربوط به همبستكى إتا ميان نمره كل سواد بدنى با متغيرهاى

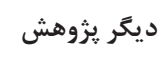

\begin{tabular}{|c|c|c|}
\hline \multicolumn{2}{|c|}{ ضريب همبستخى إِا } & \multirow{2}{*}{ متغير } \\
\hline معنادارى & آماره & \\
\hline$\cdot 1 \cdot 1$ & $\cdot 1 / 9$ & ماهيت شغلى يدر \\
\hline$\cdot 1 \cdot r$ & $\cdot / T V$ & رسته شغلى گدر \\
\hline$\cdot 1 \cdot 1$ & $\cdot / T V$ & تحصيلات يدر \\
\hline .190 & .114 & تحصيلات مادر \\
\hline$\cdot / \cdot r$ & (T/K & جنسيت \\
\hline
\end{tabular}

داده شدند. در اين مطالعه به منظور محاسبه و تجزيه و تحليل

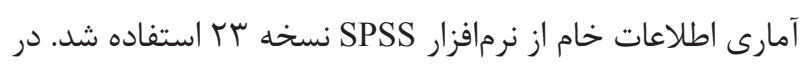
تعيين روابط همبستخى از ضريب همبستخى إتا (Eta) استفاده شد. همجنين جهت مقايسه بين كروهها و بررسى وجود تفاوت ميان

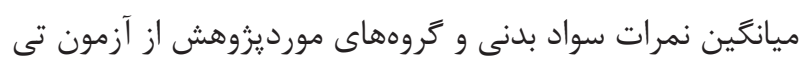

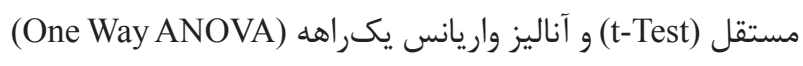

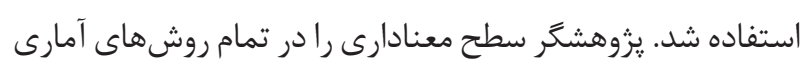
را برابر ه • • • در نظر كرفت.

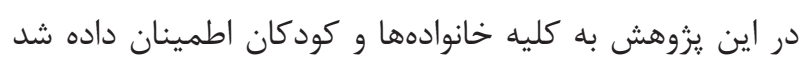

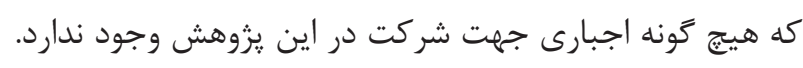
اطلاعات شركت كنند بدون نام منتشر شدند. كليه مندر جات در اين مقاله در جاى ديخرى

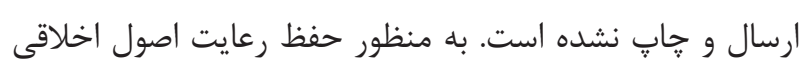

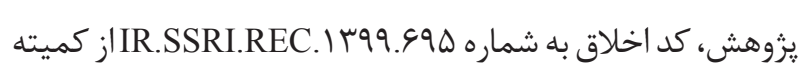

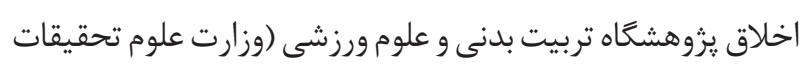
و فناورى) دريافت شد. همجنين رضايت نامه كتبى از كليه شركت

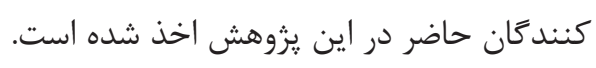

\section{يافتهها}

در مطالعه حاضر و بر اساس نتايج بلدستآمده بيشترين تعداد

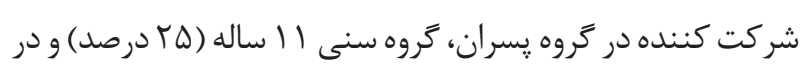

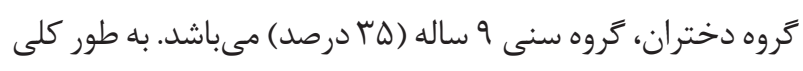

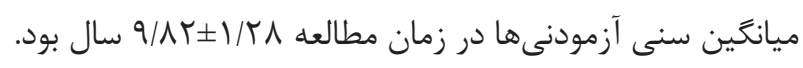

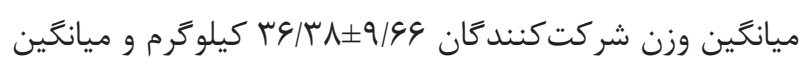

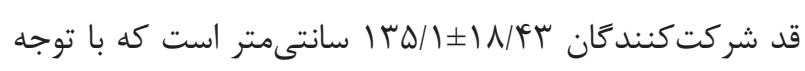
به ميانگين قد و وزن و با توجه به ميانخين شاخص توده بدنى

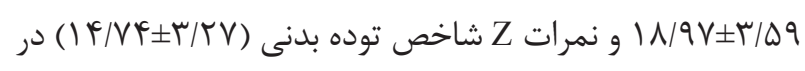
كلِ شركت كنند

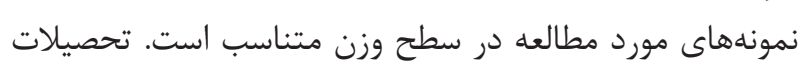

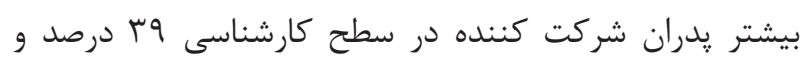

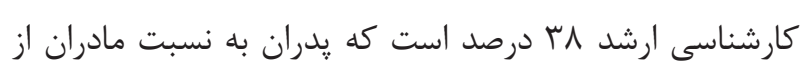
سطح تحصيلات بالاترى برخوردار هستند.

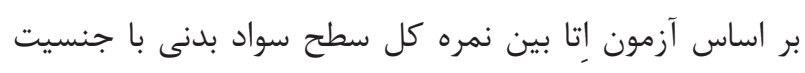

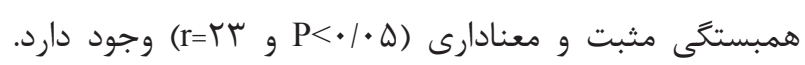




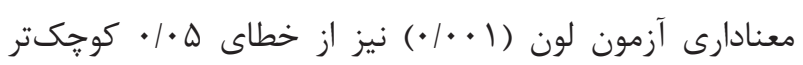

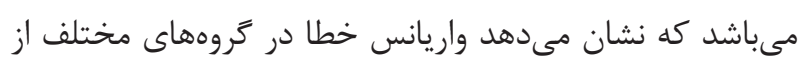
شركت كنندكان يكسان نيست و بر اساس سطح معنادارى آزمون

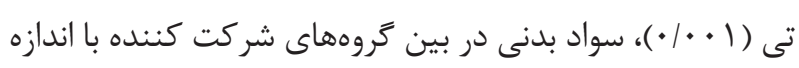
اثر كب درصد متفاوت مىباشد؛ به عبارت ديخر تفاوت در سطح

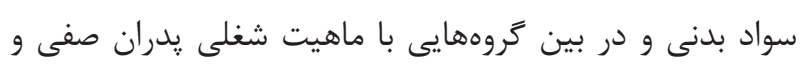

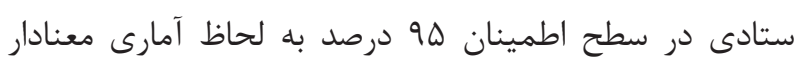

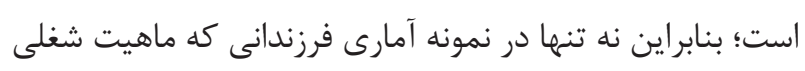

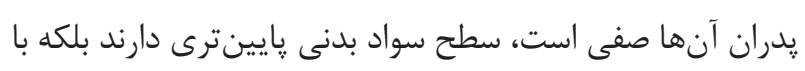

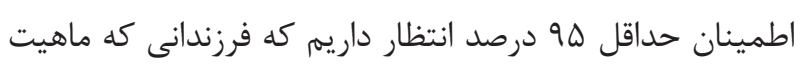
شغلى يدران آنها ستادى است در جامعه آمارى مورد مطالعه، از

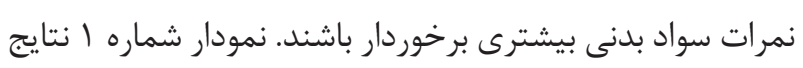
فوق را به روشنى نشان مى دهد. در ادامه، از آزمون تحليل واريانس يكسراهه (جدول بَّ) به منظور
به خرده مقياس رفتار حركتى روزانه (19|1/VYI) بود.

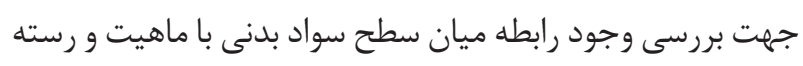

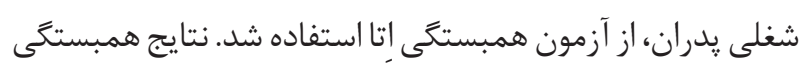

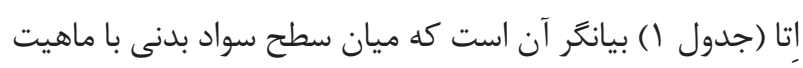
و رسته شغلى يدران همبستكى مثبت و معنادارى وجود دارد.

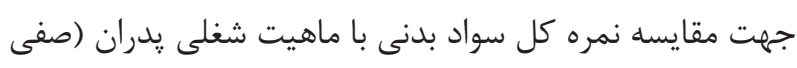
و ستادى) ابتدا شركت كنند

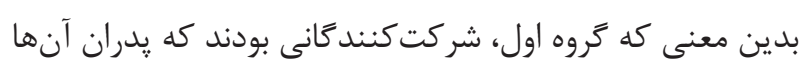

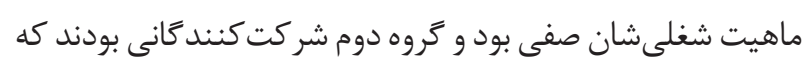

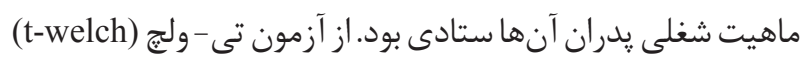

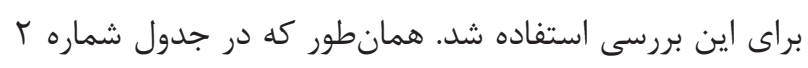
مشخص است، در تمام كروههاى شركت كننده مقدار معنادارى

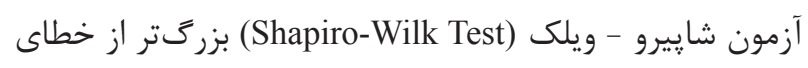

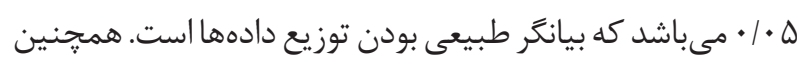

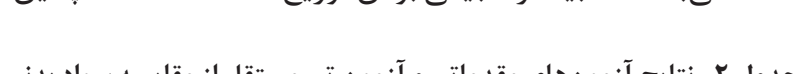
جدول r- نتايج آزمون هاى مقدماتى و آزمون تى مستقل از مقايسه سواد بدنى كودكان با ماهيت شغلى (صفى و ستادى) يدران

\begin{tabular}{|c|c|c|c|c|c|c|c|c|}
\hline \multicolumn{3}{|c|}{ 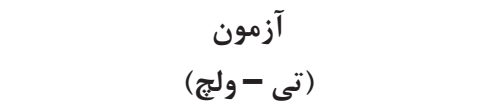 } & \multicolumn{2}{|c|}{ 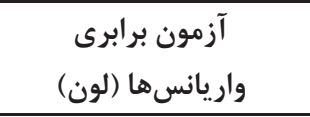 } & \multicolumn{2}{|c|}{ (شائمون نرماليتى } & \multirow[t]{2}{*}{ تروه } & \multirow[t]{2}{*}{ متغير } \\
\hline اندازه اثر & معنادارى & تى & معنادارى & آماره & معنادارى & آماره & & \\
\hline \multirow{2}{*}{ • } & \multirow{2}{*}{$\cdot / \cdot \cdot 1$} & \multirow{2}{*}{$-\psi / \Delta \Delta \Lambda$} & \multirow{2}{*}{$\cdot / \cdot \cdot 1$} & \multirow{2}{*}{$|r /| r \mid$} & $\cdot 11 \cdot r$ & . 1994 & صفى & \multirow{2}{*}{ سواد بدنى } \\
\hline & & & & & . $/ K M V$ &.$/ 9 \wedge \Delta$ & ستادى & \\
\hline
\end{tabular}

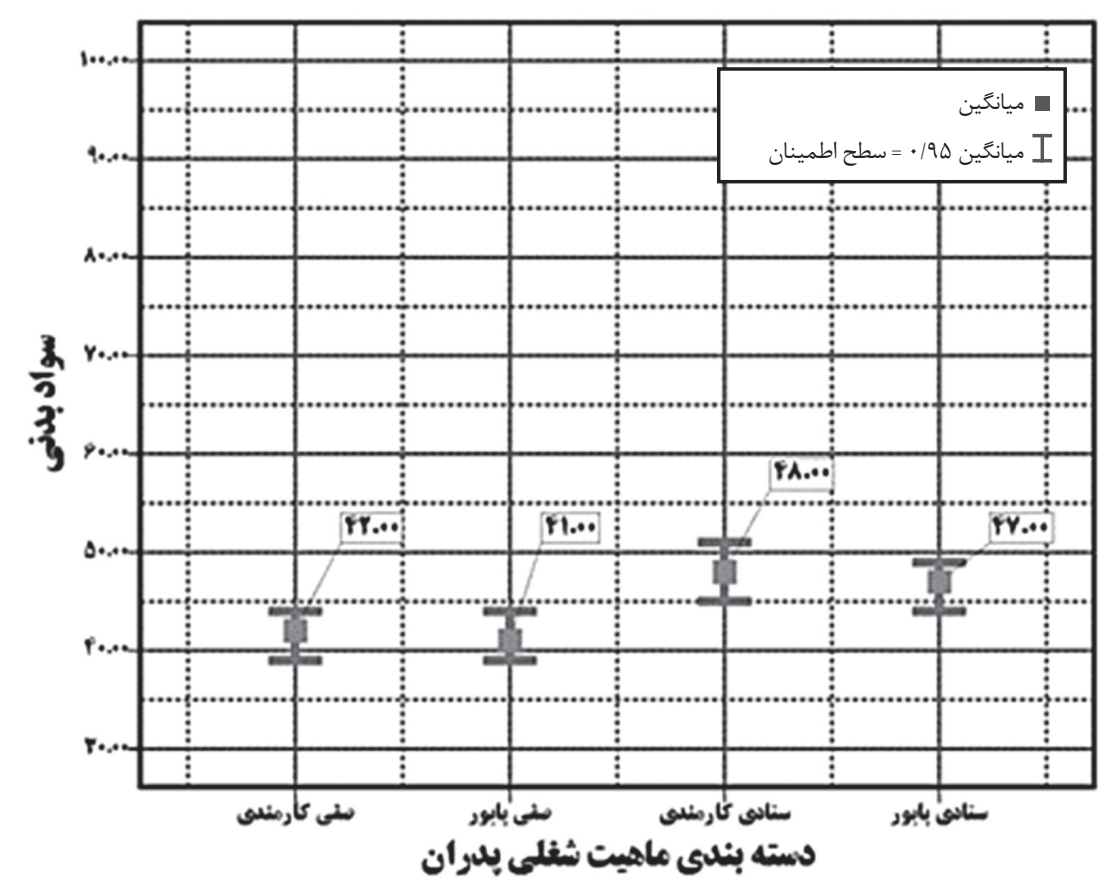

نمودار ا - نمودار جعبهاى مقايسه ميانغَين نمره كل از سواد بدنى به تفكيك ماهيت شغلى يدران 
جدول بـ - نتايج آزمونهاى مقدماتى و آزمون تحليل واريانس يكراهه از مقايسه سواد بدنى كودكان با دست بندى ماهيت شغلى يدران

\begin{tabular}{|c|c|c|c|c|c|c|c|c|}
\hline \multicolumn{2}{|c|}{ 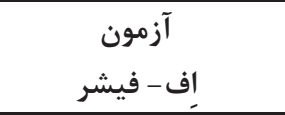 } & \multicolumn{2}{|c|}{$\begin{array}{c}\text { آزمون برابرى } \\
\text { واريانسها (لون) }\end{array}$} & \multicolumn{2}{|c|}{ 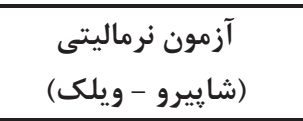 } & \multirow[t]{2}{*}{ تروه } & \multirow[t]{2}{*}{ ماهيت } & \multirow[t]{2}{*}{ متغير } \\
\hline معنادارى & آماره & معنادارى & آماره & معنادارى & آماره & & & \\
\hline \multirow{4}{*}{$\cdot 1 \cdot \cdot 1$} & \multirow{4}{*}{ V/IVr } & \multirow{4}{*}{$\cdot / \cdot V$} & \multirow{4}{*}{ F/TTK } &.$/ 971$ &.$/ 91 r$ & كارمندى & \multirow{2}{*}{ صفى } & \multirow{4}{*}{ سواد بدنى } \\
\hline & & & & .1941 &.$/ 9 \vee \wedge$ & يايور & & \\
\hline & & & & ./VG. & . 1914 & كارمندى & \multirow{2}{*}{ ستادى } & \\
\hline & & & &.$/ 11 \mathrm{r}$ &.$/ 9 \mathrm{VV}$ & يايور & & \\
\hline
\end{tabular}

شغلى پدران آنها صفى كارمند و صفى پايور است (نمودار ؟).

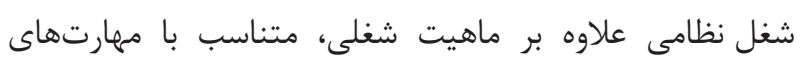
تخصصى افراد داراى دستهبندى ديخرى مىباشد كه با عنوان رسته مشخص مىشوند. رستههاى مربوطه شامل: عملياتى، آموزشى، درمانى، فنى - مهندسى، پشتيبانى و ادارى است. از آزمون تحليل واريانس يكراهه براى مقايسه سواد بدنى

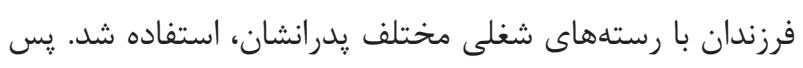
از اطمينان از برقرارى پيشفرضهاى آزمون پارامتريك تحليل

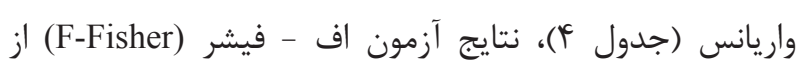
تحليل واريانس نشان داد كه تفاوت معنادارى در سطح سواد بدنى زروههاى شركت كننده وجود دارد، اين تفاوت در سطح اطمينان له درصد به لحاظ آمارى معنادار است. به كمك آزمون
بررسى دقيقتر تفاوتها در نمره كل سواد بدنى با دستهبندىهاى

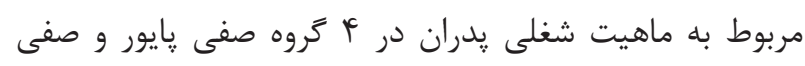
كارمندى و ستادى يايور و ستادى كارمندى استفاده شد. نتايج نشان داد كه در سطح خطاى ه • • •، ميزان سواد بدنى در بين زروهها متفاوت مىباشد و بر اساس آزمون تعقيبى تام هين و مقادير معنادارى، تفاوت معنادارى در بين نمرات (Tamhane) سواد بدنى گروه با ماهيت شغلى يدران صفى كارمند و ستادى

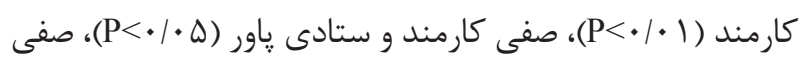

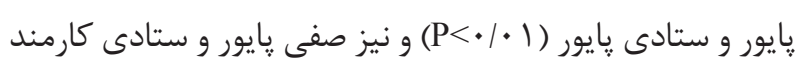

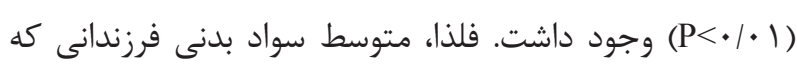
ابتدا ماهيت شغلى پِران آنها ستادى كارمند و سيس ستادى

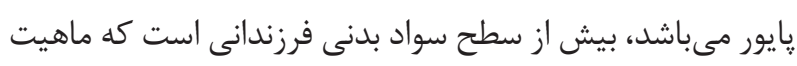

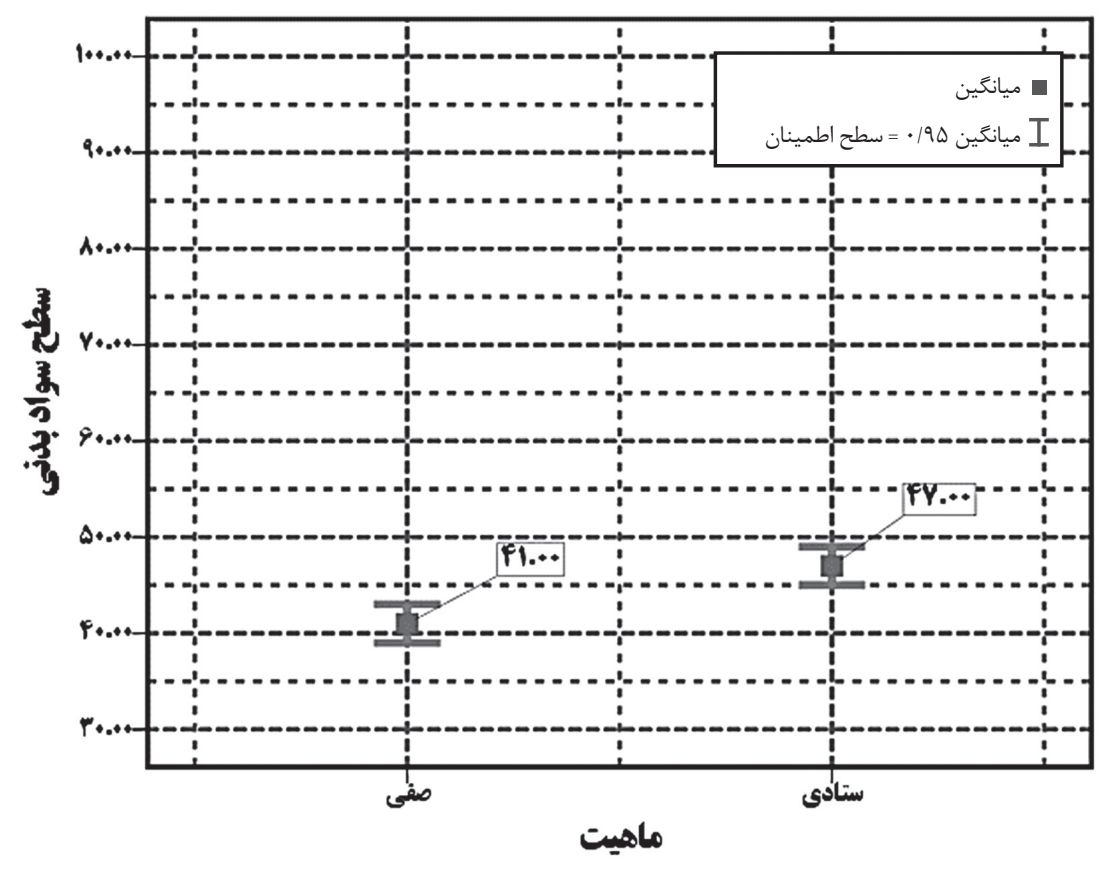

نمودار ץ- نمودار جعبهاى مقايسه ميانكَين نمره كل از سواد بدنى به تفكيك دستهبندى هاى ماهيت شغلى يدران 
جدول F - نتايج آزمون هاى مقدماتى و آزمون تحليل واريانس يكىراهه از مقايسه سواد بدنى كودكان با رسته شغلى يدران

\begin{tabular}{|c|c|c|c|c|c|c|c|}
\hline \multicolumn{2}{|c|}{ آف - فيشرن } & \multicolumn{2}{|c|}{$\begin{array}{l}\text { آزمون برابرى } \\
\text { واريانسها (لون) }\end{array}$} & \multicolumn{2}{|c|}{ 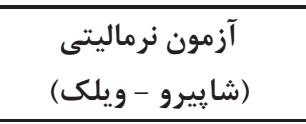 } & \multirow[t]{2}{*}{ تروه } & \multirow[t]{2}{*}{ متغير } \\
\hline معنادارى & آماره & معنادارى & آماره & معنادارى & آماره & & \\
\hline \multirow{6}{*}{$\cdot 1 \cdot \cdot 1$} & \multirow{6}{*}{ TRTM } & \multirow{6}{*}{ • } & \multirow{6}{*}{ l/Dr. } & .1941 &.$/ 91 \mathrm{~V}$ & عملياتى & \multirow{6}{*}{ سواد بدنى } \\
\hline & & & &.$|9| \cdot$ & $.198 r$ & آموزشى & \\
\hline & & & & $\cdot|\lambda| f \mid$ & .1911 & ادارى & \\
\hline & & & & • & .1919 & درمانى & \\
\hline & & & & $\cdot 1 \cdot v \cdot$ & $.19 \mu \mathrm{F}$ & فنى و مهندسى & \\
\hline & & & & $\cdot|1| \mid$ & .1984 & يشتيبانى & \\
\hline
\end{tabular}

داشتن (به خصوص براى دختران) و يا فعال بودن را از كودكان سلب مى كند. براى مثال در اين گونه از شهرك هاى سازمانى، فضا

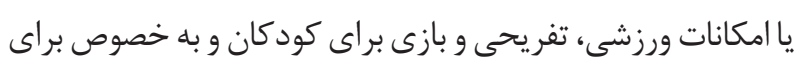
دختران در مقايسه با يسران بسيار محدودتر است و دختران اين امكان راندارند تا از فضاهاى بازى استفاده كنند. اين موضوع خود با بزرگتر شدن دختران به مراتب سختتر شده و محدوديتها را براى آنها بيشتر مى كند؛ جرا كه گزارشها نشان داد كه گَروه دختران نسبت به گروه يسران شركت كننده سطح سواد بدنى ״ايينترى دارند، در واقع سواد بدنى گسران در سطح متوسط رو به يايين و سطح سواد بدنى دختران در حد ابتدايى ارزشيابى شد. از طرفى هم اخر امكانات ورزشى در اين محلهاى مسكونى موجود باشد، به نظر مىرسد كه يا بسيار كم از آنها استفاده مى كنند و يا استفاده از اين مكانهاى ورزشى بر اساس برناملريزى مناسب

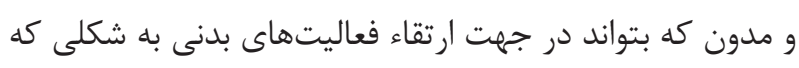
در قالب مهارتهاى بنيادين در رشتههاى ورزشى مختلف انجام

$$
\text { بخيرد، وجود ندارد. }
$$

يافتهها نشان دادند كه رابطه مثبت و معنادارى ميان سطح سواد بدنى با ماهيت، رسته و سطح تحصيلات وجود دارد، همرنين

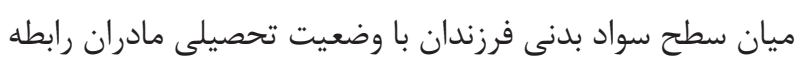

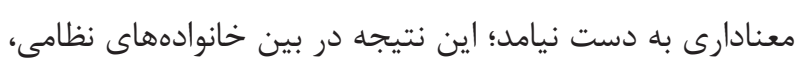
نشان دهنده نقش و اهميت حضور پدرانى با تحصيلات بالا در جهت پيشرفت سطح سواد بدنى كودكان است. متناسب با هدف اصلى يزوهش مشخص شد كه يكى از عواملى كه مىتواند سطح سواد بدنى اين كودكان (با تأكيد بيشتر براى
تعقيبى توكى (Tukey) مشخص شد كه در بين نمرات سواد بدنى جهار زوج از گروهها تفاوت معنادارى وجود دارد. اين تفاوت در

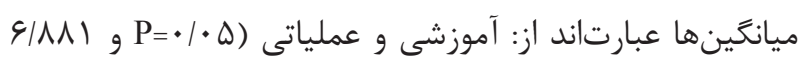

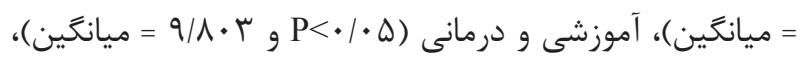

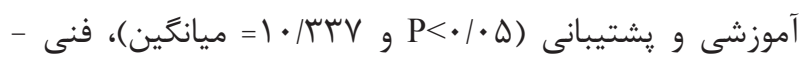

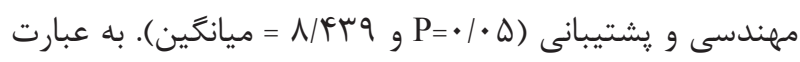
ديخر، گروهى كه رسته شغلى يدرانشان آموزشى است نسبت به سه گروه درمانى، يشتيبانى و فنى، سواد بدنىشان بيشتر است

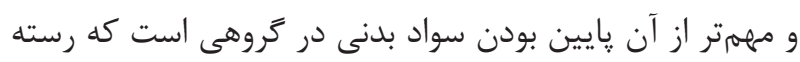
شغلى يدرانشان عملياتى است.

\section{بحث و نتيجه كيرى}

هدف اين مطالعه، تعيين رابطه ميان سطح سواد بدنى كودكان 1 تا ז ا ساله با برخى از ويزگگىهاى شغلى يدران نظامى آنها بود. بررسى يافتههاى اوليه از نتايج سطوح سواد بدنى كود كان نشان داد كه ميانگين هريك از جهار فاكتور سواد بدنى (شايستخى جسمانى، فعاليت بدنى روزانه، درك و دانش و انخيزش و اعتمادبهنفس) و نمره كل سواد بدنى در سطح ابتدايى قرار دارد. در واقع فرزندان

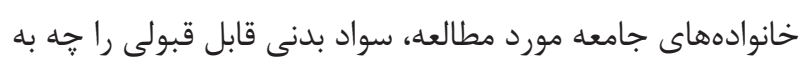
لحاظ كمى و جه به لحاظ كيفى به دست نياوردند. اين در حالى است كه از ميان خرده مقياسهاى سواد بدنى، خرده مقياس رفتار حركتى روزمره، ضعيفترين ميانگين را در بين ديخر خرده

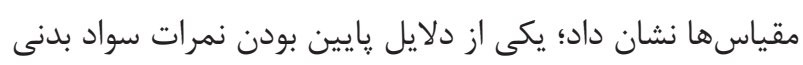
را مىتوان به محل سكونت اكثر خانوادههاى نظامى دانست. جرا كه در اين شهركها محدوديتهايى وجود دارد كه امكان تحرى 
يدرانى كه در رستههاى عملياتى و يشتيبانى فعاليت دارند سطح

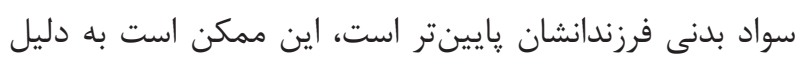

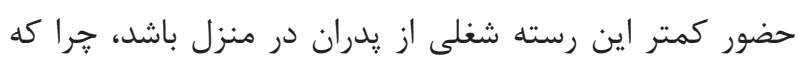

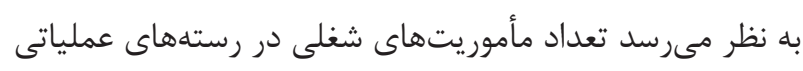
بيشتر است.

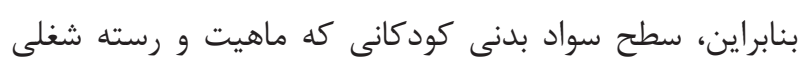

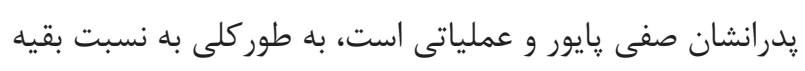

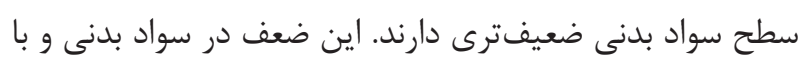

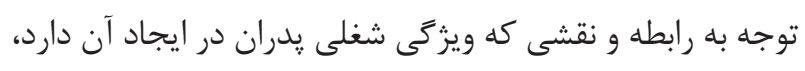

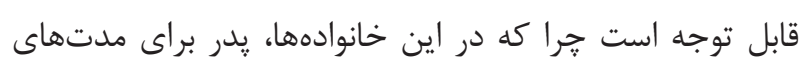

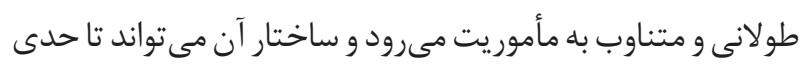
شبيه خانوادههاى تك والدى شود كه مادر سريرستى خانواده را راني به عهده دارد. در ظاهر نقش يدرى وجود ندارئ ندارد، اقتدار او كاسته

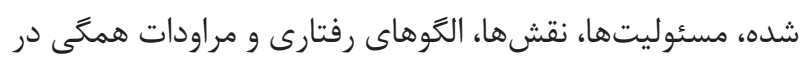

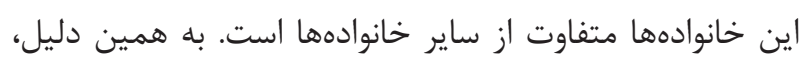

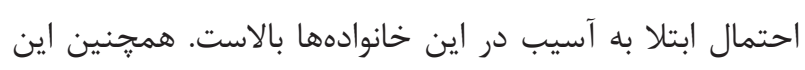

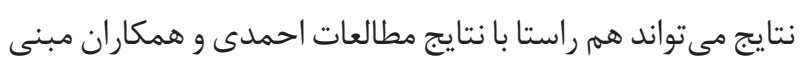
بر اهميت حضور كمى و كيفى بدران نظامى در منزل كه ارتباط

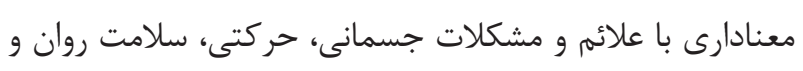

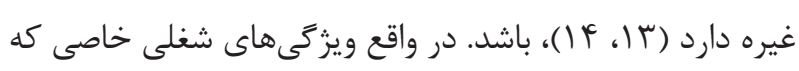

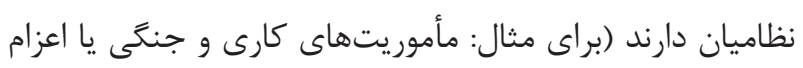
به مناطق مرزى دوردست با كمترين امكانات رفاهى و فرهنكى و وارئ

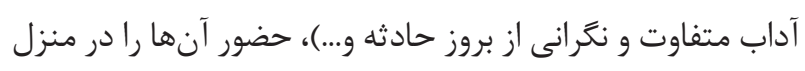

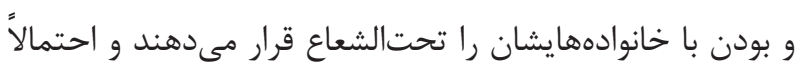
همين ويزگى هاى شغلى، بر نتايج ما در سطح سواد بدنى فرزندان

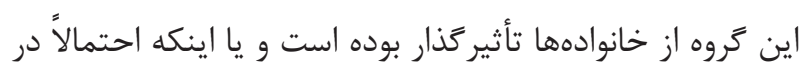

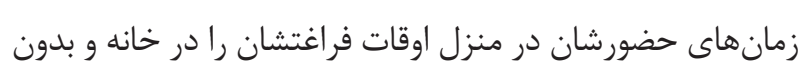

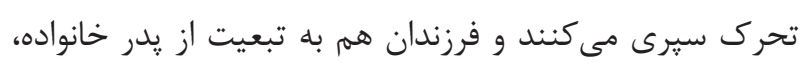

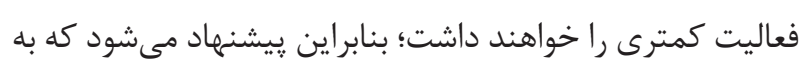

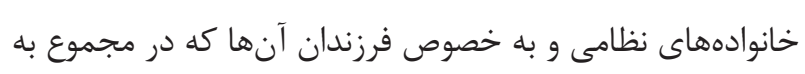

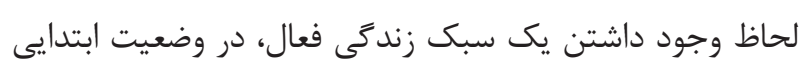
(ضعيف) قرار دارند، توجه بيشترى بشود تا فرزندان اين خانوادهها

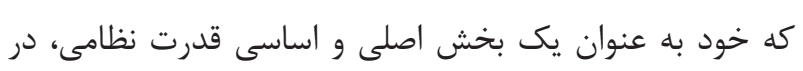

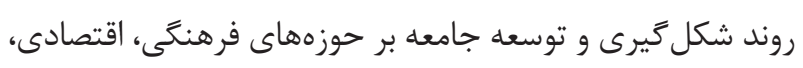

يا بهطور كلى نظاميان به لحاظ شغلى است؛ بنابراين، از آنجايى

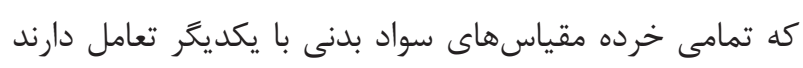

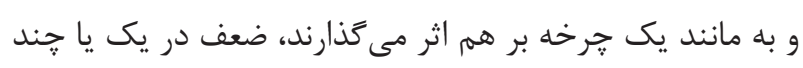

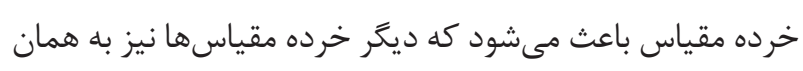

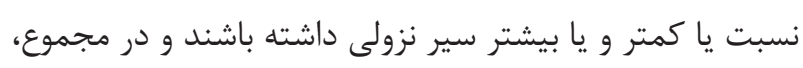

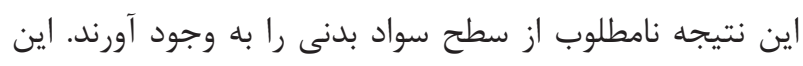

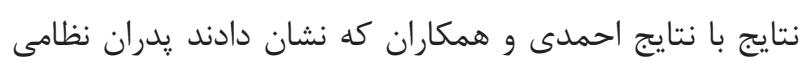

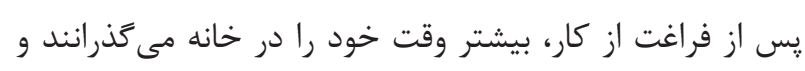

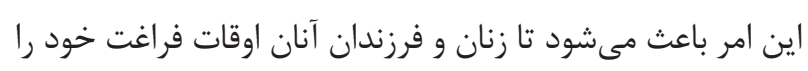
در خانه و بدون هيج تحرك مفيد و مناسبى سيرى كنند (1) (1).

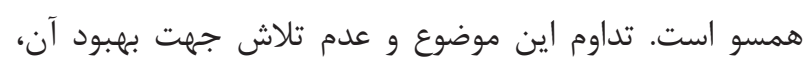
باعث مىشود كه فقر حركتى از سوى بدران نظامى تقويت كردد

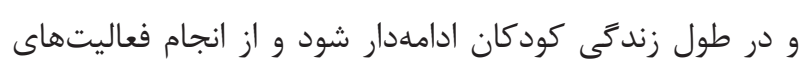
بدنى بيشتر دور شوند و كارهاى غيرفعال انجام دهند، در نهايت

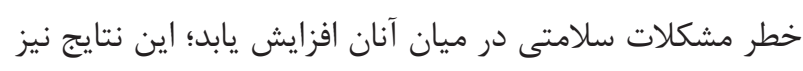

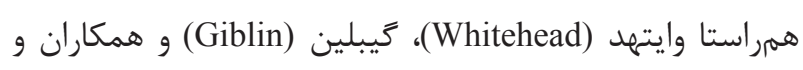

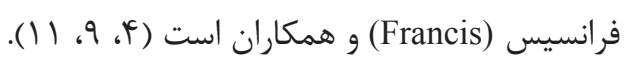
نتايج نشان داد كه ميان سطح سواد بدنى و ماهيت شغلى يدران كه داراى دو دسته صفى و ستادى هستند و هركدام به دو طبقه نان كارمندى و پايور نيز تقسيم مى شوند تفاوت معنادارى وجود دارد. بر اساس يافتهها به دست آمده كود كانى كه ماهيت شغلى يدران

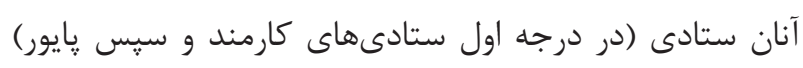

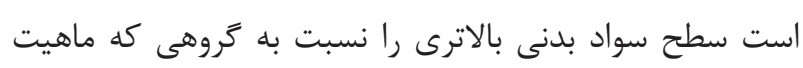

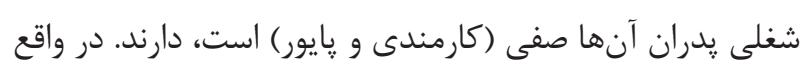

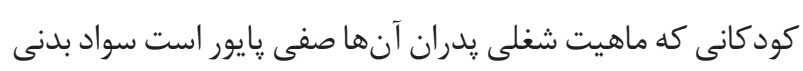

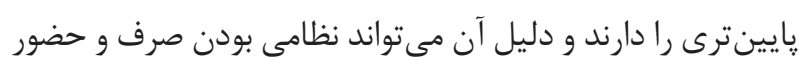

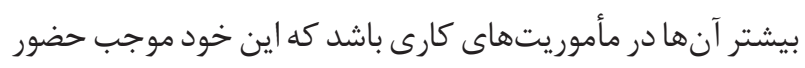

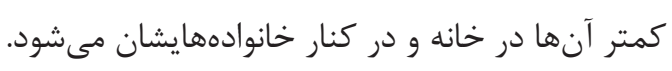

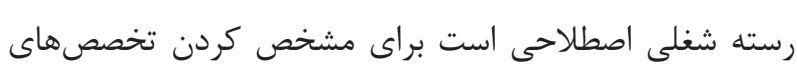

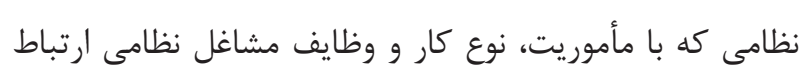

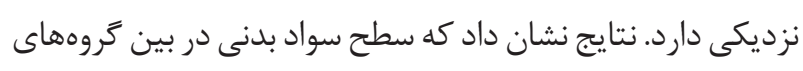
كودكان با رستههاى شغلى مختلف يدرانشان در سطح اطمينان

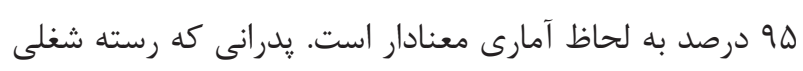

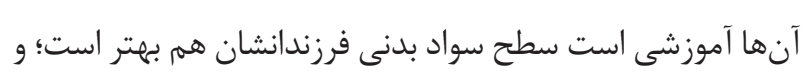


اطمينان، اين محدوديتها را به حداقل برسانند. همجنين در

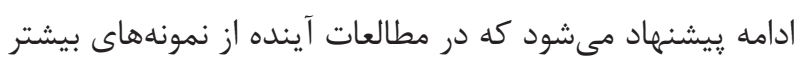

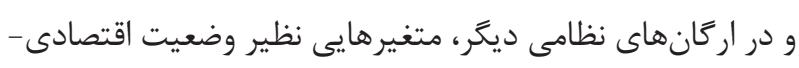

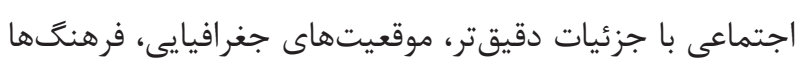

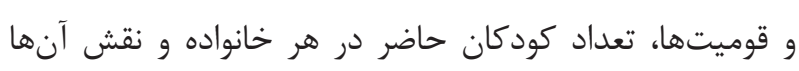

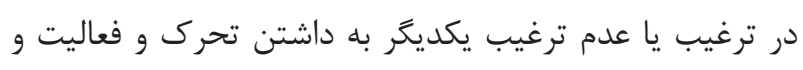

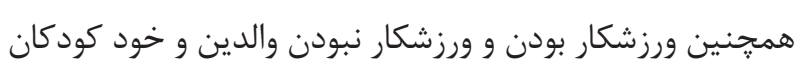
يا ديدَّاهشان نسبت به فعاليت بدنى، مورد بررسى و وتحليل قرار

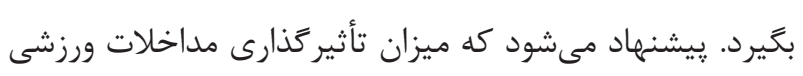

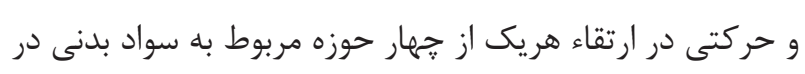
تحقيقات بعدى مورد مطالعه قرار خيرند.

تشكر و قدردانى

نويسندگان مقاله از كليه مديران و مسئولين ذى فربط در در امور

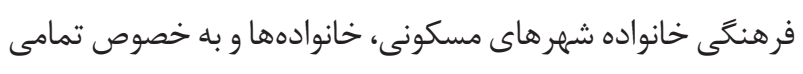

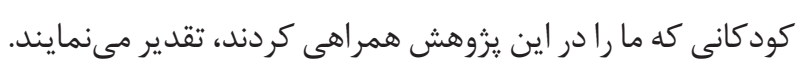

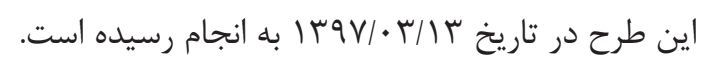

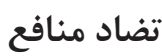

بدين وسيله نويسندكان تصريح مىنمايند كه هيجزَنه تضاد منافعى در خصوص يزوهش حاضر وجود ندارد.

\section{References}

1- Payne V, Isaacs L. Human motor development: A lifespan approach: Routledge; 2017.

2- Gabbard CP. Lifelong motor development: Pearson Higher Ed; 2011.

3- Tremblay M, Lloyd M. Physical literacy measurement: The missing piece. Physical \& Health Educat J. 2010;76(1):26-30.

4- Whitehead M. The Concept of Physical Literacy. European J Physical Educat. 2006;6(2):127-38. http://dx.doi. org/10.1080/1740898010060205

5- Fisher AB, Reilly JJ, Kelly LA, Montgomery CO, Williamson AV, Paton JY, Grant ST. Fundamental movement skills and habitual physical activity in young children. Medicine \& Science in Sports \& Exercise. 2005;37(4):684-8. doi:10.1249/01. MSS.0000159138.48107.7D
علمى و فناورى به طور فعال و گسترده حاضر هستند، بتوانند جايگاه بهترى را به لحاظ برخوردارى از يك سبك زندىى فعال و سالم همراه با تندرستى در ميان ديخر اعضاى جامعه داشته باشند. با توجه به نتايج اين يزوهش مبنى بر اينكه ويزگى هاى شغلى يدران

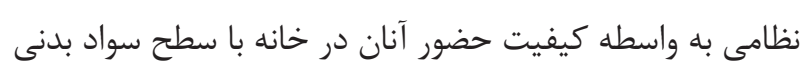

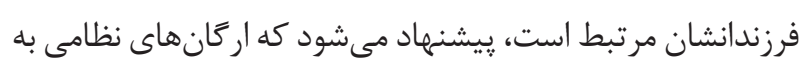
ويزه سازمان فرهنگى و خانواده تلاش بيشترى در ارائه خدمات و برنامههاى ورزشى و تفريحى - حركتى (به خصوص در شهرك هاى مسكونى خانوادهها نظامى) تدوين نمايند و البته طراحى اين نوع برنامهها بيشتر به شكل گروهى و با حضور يررنت يدران صورت

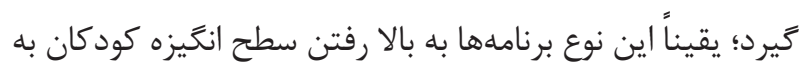

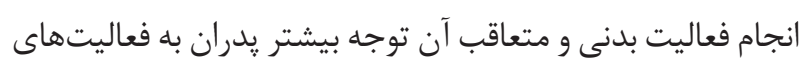
حركتى كود كانشان و درنهايت به بالا رفتن سطح سواد بدنى آنان در دراز مدت منجر مىشود و اين خود مىتواند به كاهش فقر حركتى و بيمارىهاى ناشى از آن هم نيز كمك بسيارى كند. به مانند هر يزوهش ديخرى در اين يزوهش هم محدوديتهاى وجود داشت كه شامل عدم امكان دسترسى دقيق به حجم جامعه ليه يزوهش به دليل موقعيت نظامى، وجود يكسرى از حساسيتها و

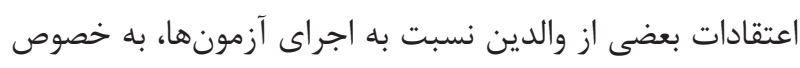
در گروه دختران و همجنين احتمال خوددارى از ارائه نظرات صحيح افراد در تكميل برسشنامة مربوط به اطلاعات يدران از محدوديتهاى اصلى بود كه البته محققين سعى نمودند با جلب

environment on children's fine- and gross motor skills. Early Child Development and Care. 2018;190(8):1225-32. http://dx.doi.org/10 $.1080 / 03004430.2018 .1526791$

7- Longmuir P. Understanding the physical literacy journey of children: the Canadian assessment of physical literacy. ICSSPE BULLETIN-J Sport Sci Phys Educ. 2013;65(12.1).

8- Whitehead M. Physical literacy: Throughout the lifecourse: Routledge. 2010.

9- Giblin S, Collins D, Button C. Physical literacy: importance, assessment and future directions. Sports Med 2014;44(9):117784. http://dx.doi.org/10.1007/s40279-014-0205-7 www.ncbi.nlm. nih.gov/pubmed/24898813

10- Longmuir P, Boyer C, Lloyd M, Yang Y, Boiarskaia E, Zhu W, et al. The Canadian assessment of physical literacy: methods for children in grades 4 to 6 ( 8 to 12 years). BMC Public Health 
2015;15(1):767. http://dx.doi.org/10.1186/s12889-015-2106-6 www.ncbi.nlm.nih.gov/pubmed/26260572

11- Francis C, Longmuir P, Boyer C, Andersen L, Barnes J, Boiarskaia E, et al. The Canadian assessment of physical literacy: development of a model of children's capacity for a healthy, active lifestyle through a Delphi process. J Phys Act Health. 2016;13(2):214-22. http://dx.doi.org/10.1123/jpah.2014-0597 www.ncbi.nlm.nih.gov/ pubmed/26106940

12- Valadi S, Hamidi M. Studying the level of physical literacy of students aged 8 to 12 years. Research on Educational Sport 2020: doi: 10.22089/res.2018.5090. 2018. (Persian)

13- Ahmadi K, Yelveh M, Afshardir B, Khodabandeh L. Effect of father's degree and quality on mental health of offspring of military personnel. J Behav Sci 2013;7(3):239-44.

14- Ahmadi K, Abdolmalaki H, Azmarsabadi E, Reyasi F. The quality of spending leisure time and its relation to cultural and social vulnerability among military families. Sports Psychology 2010;1(2):1-12.

15- Ahmadi K, Bigdeli. Monitoring children and its effects in families of IRGC staff. J Behav Sci 2008;1(1):87-96.

16- Tajbakhsh M, Tavazoa R. The impact of long-term missions on the health of the military family. The first biennial conference on preventive medicine and marine sanitation on surface and submarine vessels 2009.

17- Heidarali H. Research methodology in behavioral science: Research Bases: Samt Publication; 2013.

18- Valadi S, Sheykhi Y. Comparison of Physical Literacy of both Male and Female Elementary Students in Second To Sixth Grade. 11th International Congress on Sports Sciences; Tehran, Iran 2018. http://dx.doi.org/ 10.22089/11thconf.2018.1698 